\title{
Distribution patterns of Hydropsychids and Rhyacophilids species (Trichoptera) in a not regulated Mediterranean river (SW Spain)
}

\author{
Antonio Ruiz García ${ }^{*, 1}$ and Manuel Ferreras-Romero ${ }^{1}$ \\ Departamento de Sistemas Físicos, Químicos y Naturales. Universidad Pablo de Olavide. 41013 Sevilla, Spain. \\ *Corresponding author: aruigar@upo.es
}

Received: 7/8/07

Accepted: 28/5/08

\begin{abstract}
Distribution patterns of Hydropsychids and Rhyacophilids species (Trichoptera) in a non-regulated Mediterranean river (SW Spain)

This paper investigates the longitudinal ordination of the Hydropsychidae and Rhyacophilidae species present in the high basin of the Hozgarganta River. The ordination of the Hydropsychids species present in the basin show three distribution patterns: Diplectrona felix and Hydropsyche infernalis are confined to the head streams; $H$. siltalai and $H$. iberomaroccana are distributed throughout the entire study zone, although the second one does not reach the highest sections of the basin; finally, H. lobata occupies the lowest sections, specially in the main axis of the river. The two Rhyacophila species studied show also a well differentiated distribution. $R$. fonticola is more abundant in the gorges and high sections, whereas $R$. munda prefers the riverbed of the main river, although it's also found in some tributaries. Even in these intermediate sections, the segregation between the two species is almost perfect.

The water permanence in the riverbeds influences the distribution of some species. We have found that D. felix and H. infernalis inhabit the permanent sections of the stream heads whereas $H$. iberomaroccana significantly dominates the intermittent ones. $H$. siltalai, H. lobata, $R$. fonticola, and R. munda do not show a significant preference for any type of riverbed (permanent, intermittent, or ephemeral). It is interesting to highlight the survival of some $H$. iberomaroccana larvae in isolated pools during the summer. We suggest the possibility that these larvae survive thanks to the existence of a weak underground flow of subsurface origin between adjacent pools.
\end{abstract}

Key words: Hydropsychidae, Rhyacophilidae, distribution, seasonality, Hozgarganta river basin.

\section{RESUMEN}

Patrones de distribución de especies de Hydropsychidae y Rhyacophilidae (Trichoptera) en un río mediterráneo no regulado (Suroeste de la Península Ibérica)

En el presente trabajo se investiga la ordenación longitudinal de las especies de Hydropsychidae y Rhyacophilidae presentes en la cuenca alta del río Hozgarganta. La ordenación de las especies de Hydropsychidae presentes en la cuenca muestra tres patrones de distribución: Diplectrona felix e Hydropsyche infernalis están confinadas en los arroyos de cabecera; H. siltalai $e \mathrm{H}$. iberomaroccana están distribuidas por toda la zona de estudio, aunque la segunda no alcanza los tramos más altos de la cuenca; por último, H. lobata ocupa los tramos más bajos, especialmente en el eje principal del río. Las dos especies de Rhyacophila estudiadas también muestran una distribución bien diferenciada. R. fonticola es más abundante en las gargantas y tramos altos, mientras que R. munda prefiere el cauce del río principal, aunque también se encuentra presente en algunos tributarios. Incluso en estos tramos intermedios la segregación entre ambas especies es casi perfecta.

La permanencia del agua en los cauces influye en la distribución de algunas especies. Hemos encontrado que D. felix $e$ $\mathrm{H}$. infernalis habitan los tramos permanentes de cabecera, mientras que $\mathrm{H}$. iberomaroccana domina de forma significativa en los intermitentes. H. siltalai, H. lobata, R. fonticola $y$ R. munda no muestran una preferencia significativa por algún tipo de cauce (permanente, intermitente o efimero). Es interesante resaltar la supervivencia de algunas larvas de $\mathrm{H}$. iberomaroccana en pozas aisladas durante el verano. Sugerimos la posibilidad de que estas larvas sobrevivan gracias a la existencia de un débil flujo subterráneo de origen freático entre pozas adyacentes.

Palabras clave: Hydropsychidae, Rhyacophilidae, distribución, estacionalidad, cuenca río Hozgarganta. 


\section{INTRODUCTION}

Both Hydropsychids and Rhyacophilids are two of the most diverse families of caddisflies in the Iberian Peninsula, in addition to the Hydroptilidae (González et al., 1987) and they are widespread in all Spanish catchments.

The ecological differences between both families are a consequence of the way of using the silk (Mackay \& Wiggins, 1979). The Rhyacophilids have free-living larvae that only use the silk before pupation, whereas the Hydropsychidae are sedentary and net-building along with other filterfeeders, therefore they perform an important function in the treatment of the organic matter in fluvial ecosystems (Basaguren \& Orive, 1991). In the Mediterranean rivers they are, together with the Hydroptilidae, the most important family of caddisflies due to their abundance and species' richness (Giudicelli et al, 1985).

Many studies have pointed out a longitudinal replacement of Hydropsychidae species (García de Jalón, 1986, Camargo, 1992, GallardoMayenco et al., 1998). The environmental factors change along the watercourse and the species occupying a particular position in the longitudinal sequence seem to have appropriate suites of physiological and behavioural characteristics (Edington \& Hildrew, 1995).

Mediterranean climatic regions are distributed around the world, and seasonality and variability in rainfall is its main characteristic. Although the seasonal precipitation pattern is highly predictable in Mediterranean climatic areas, annual rainfall can vary largely from year to year (Gasith \& Resh, 1999). As a consequence of this climatic pattern, flow irregularity is one of the most important features of the Mediterranean rivers (Giudicelli et al., 1985), with a seasonal pattern of high discharge during the wet period, which is followed by low discharge in the summer. Although, in some areas, they can be dry.

Aquatic insects that live in temporary ponds have developed a series of strategies that allow them to survive a periodic loss of habitat (Wiggins et al, 1980). Several species of Trichoptera inhabiting temporary streams have developed special adaptations. This is also the case of
Stenophylax species, which are well adapted to replace other limnephilids in temporary waters: all species are univoltine; the eggs are enclosed by a gelatinous matrix that allows them to survive long periods of time out of water; adult or ovarian diapause is present; the burrowing larvae can use the humid substratum during low-water periods, and the pupal cases are buried vertically in the substratum. The Rhyacophilids larvae are probably the caddisflies that are most restricted to conditions of high current-speed (Edington \& Hildrew, 1995), occupying, generally, headwaters. Hydropsychids larvae are rheophilic inhabitants of stream rifles (Edington \& Hildrew, 1973; Fuller \& Mackay, 1980; Osborn \& Herricks, 1987; Bonada, 2003). Because of its high dispersion capacity, the survival of both Rhyacophilids and Hydropsychids species during the dry period in Mediterranean streams may involve a high capacity for the reconstruction of colonies from nearby permanent sources (Resh, 1982; 1992).

Though the longitudinal distribution of the Hydropsychids has been largely studied, we think that studies on the longitudinal zonation of endemic or restricted distribution range species, like some present in this catchment, are necessary. The aim of this study was to search for the response of Hydropsychid and Rhyacophilid species present in the river, to the spatial-temporal gradients, as well as to establish their relationship with the water permanence.

\section{METHODS}

\section{Study area and sampling methods}

The Hozgarganta River basin covers a surface of $245 \mathrm{~km}^{2}$ and it extends in a NW - SE direction (Fig. 1). The system drains the Eastern slopes of the mountain range of the Aljibe and after $55 \mathrm{~km}$ the watercourse joins the River Guadiaro, near its mouth (Blanco et al., 1991).

The study area included all of the river basins within the limit of the Los Alcornocales Natural Park. The river is born at $160 \mathrm{~m}$ a. s. l., at the confluence of the Pasada Blanca canyon and the La Sauceda gorge. The first one flows 


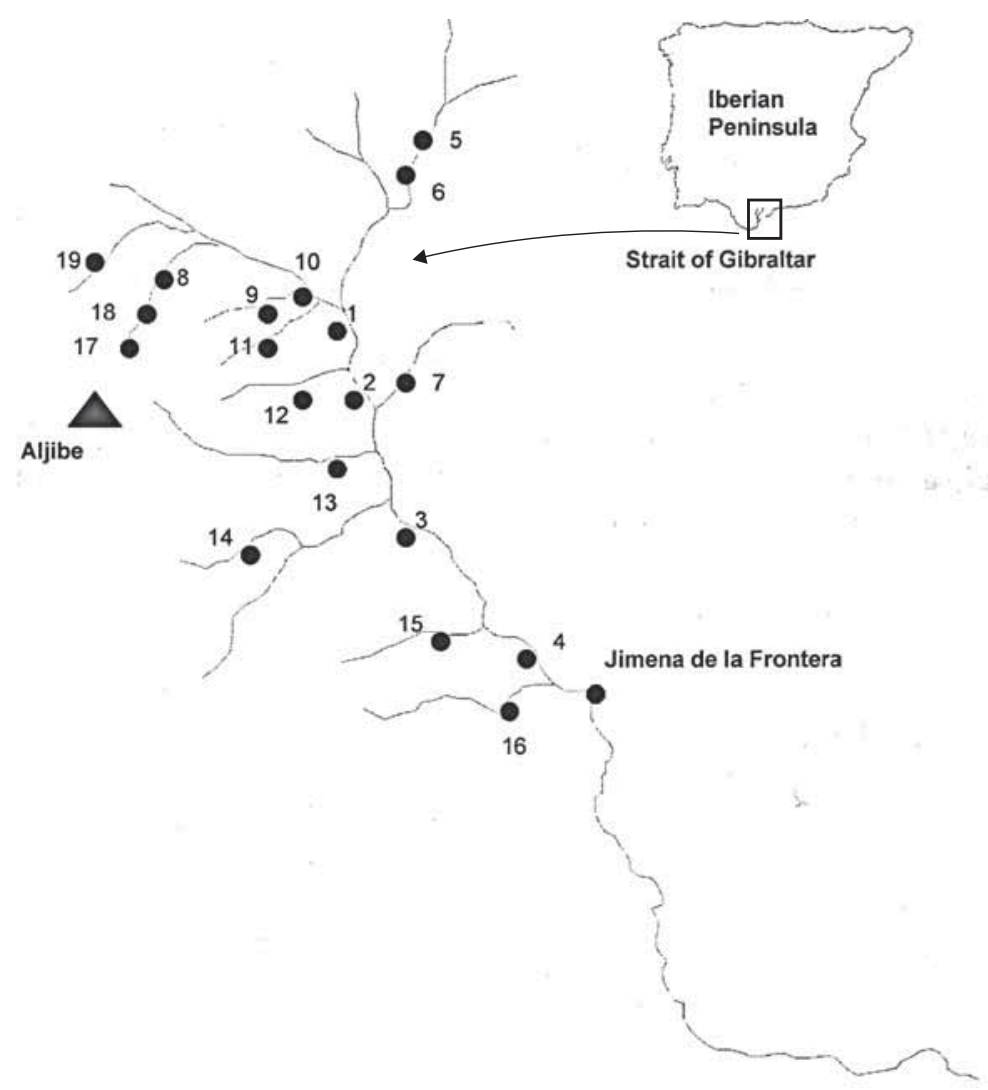

Figure 1. Study area. Localización del área de estudio.

through calcareous lands and the second one flows through the Aljibe unit (dominated by sandstone with marl and clay).

The study area is covered by a well preserved Mediterranean forest, in which the cork oak (Quercus suber) dominates. Other common species are the Andalusian gall oak (Quercus canariensis) and the wild olive (Olea europaea). In the humid and shaded canyons there are remains of a subtropical forest, a relict from the tertiary age (e.g. Laurus nobilis, Rhododendrum ponticum) and an arboreal stratum of alder-trees (Alnus glutinosa), willows (Salix atrocinerea, Salix pedicellata), and ash-trees (Fraxinus angustifolia) (Jurado-Doña, 2002). In this basin, the land is mostly used for cork oak forest exploitation and extensive ranching.

The flows in successive years show the typical irregularity of the Mediterranean rivers, with dry and wet alternating periods
(Fig. 2a). The average annual flow in the period $1980 / 99$ was $1050 \mathrm{~m}^{3} \mathrm{~s}^{-1}$. In figure $2 \mathrm{~b}$ we can see that the year when the study was performed (1997) was a wet period.

Another important hydrological feature is the seasonality (Table 1). The maximum registered annual flows are in autumn and early winter, whereas in summer the superficial current disappears, and the water is limited to isolated pools. The average annual period in which there is no superficial flow is 2.65 months (range: 0-6 months, $n=20$ years).

Nineteen sampling sites were chosen, four in the river's main channel and the rest on the tributaries (Fig. 1).

From November 1996 through December 1997 samplings were carried out in November (1996), February, March, April, June, August, October, and December of 1997. In June, Eca and Ere sampling sites (Table 1) were dry and there- 
Table 1. Mean values of the physical-chemical parameters measured in the Hozgarganta basin. Cond: conductivity; $\mathrm{Cl}^{-}$: chloride; Alk: alkalinity; $\mathrm{O}_{2}$ : dissolved oxygen; Temp: temperature; Altit: altitude; Season: seasonality *: 1. permanent flow; 2. ephemeral; 3. intermittent. Inv: invaluable. Valores medios de los parámetros físico-químicos medidos en la Cuenca del río Hozgarganta. Cond: conductividad; $\mathrm{Cl}^{-}$: cloruros; Alk: alcalinidad; $\mathrm{O}_{2}$ : oxígeno disuelto; Temp: temperatura; Altit: altitud; season: estacionalidad *: 1. flujo permanente; 2. efímero; 3. intermitente. Inv: valor no detectado.

\begin{tabular}{|c|c|c|c|c|c|c|c|c|c|c|c|c|c|}
\hline $\mathrm{N}^{\circ}$ & Cod. & Sampling site & $\begin{array}{l}\text { Cond } \\
\mu \mathrm{S} / \mathrm{cm}\end{array}$ & $\begin{array}{c}\mathrm{Cl}^{-} \\
\mathrm{mg} / \mathrm{l}\end{array}$ & $\begin{array}{c}\text { Alk } \\
\text { meq/l }\end{array}$ & $\begin{array}{c}\mathrm{O}_{2} \\
\mathrm{mg} / \mathrm{l}\end{array}$ & $\begin{array}{c}\text { Temp } \\
{ }^{\circ} \mathrm{C}\end{array}$ & Altit a. s. 1. & Order & Season * & $\begin{array}{l}\mathrm{NO}_{3}^{-} \\
\mathrm{mg} / \mathrm{l}\end{array}$ & $\begin{array}{c}\mathrm{PO}_{4}^{=} \\
\mu g a t / 1\end{array}$ & $\begin{array}{c}\mathrm{NH}_{4}^{+} \\
\mathrm{mg} / \mathrm{l}\end{array}$ \\
\hline 1 & E1 & Diego Duro & 630 & 122 & 2.1 & 6.7 & 16.9 & 155 & 4 & 3 & 0.2 & 0.8 & 0.02 \\
\hline 2 & Ecñ & Puente las Cañillas & 639 & 126 & 1.9 & 8.5 & 20.5 & 145 & 4 & 3 & 0.01 & 0.4 & 0.06 \\
\hline 3 & Eher & Herrunbroso & 428 & 83 & 1.9 & 9.5 & 19.1 & 110 & 4 & 2 & inv & 0.2 & inv \\
\hline 4 & E2 & Jimena de la Frontera & 249 & 53 & 1.5 & 9.3 & 20.1 & 35 & 4 & 2 & inv & 0.2 & 0.01 \\
\hline 5 & Epbm & $G^{\mathrm{a}}$ Pasada Blanca 1 & 368 & 53 & 2.6 & 5.1 & 18.1 & 250 & 3 & 3 & 0.02 & 0.4 & 0,01 \\
\hline 6 & Epbh & $\mathrm{G}^{\mathrm{a}}$ Pasada Blanca 2 & 433 & 61 & 3.0 & 5.1 & 18.2 & 245 & 3 & 3 & 0.01 & 0.2 & 0.03 \\
\hline 7 & Eo & Garganta de la Balsa & 168 & 49 & 2.1 & 7.3 & 16.8 & 145 & 1 & 3 & 0.005 & 0.3 & 0.02 \\
\hline 8 & Ero & $\mathrm{G}^{\mathrm{a}}$ Pasada Llana & 148 & 27 & 1.4 & 8.7 & 16.0 & 500 & 2 & 3 & 0.007 & 0.2 & 0.02 \\
\hline 9 & Eca & $\mathrm{A}^{\circ}$ Carnero & 123 & 20 & 1.2 & 7.8 & 10.9 & 360 & 1 & 2 & inv & inv & inv \\
\hline 10 & Esa & Garganta de la Sauceda & 1605 & 490 & 1.9 & 7.4 & 18.6 & 230 & 3 & 3 & 0.005 & inv & 0.02 \\
\hline 11 & Edi & $\mathrm{A}^{\circ}$ Reinoso (Diego Duro) & 95 & 20 & 1.2 & 7.7 & 15.1 & 320 & 1 & 2 & inv & inv & inv \\
\hline 12 & Ere & $\mathrm{A}^{\mathrm{o}}$ Reinoso & 168 & 25 & 1.7 & 8.4 & 11.8 & 160 & 1 & 2 & inv & inv & inv \\
\hline 13 & Emo & Garganta de Moracha & 180 & 24 & 1.9 & 9.7 & 15.1 & 170 & 2 & 2 & inv & inv & inv \\
\hline 14 & Ehu & Garganta del Huevo & 142 & 26 & 1.3 & 9.6 & 14.4 & 230 & 2 & 2 & inv & inv & 0.01 \\
\hline 15 & Ega & Garganta de Gamero & 326 & 80 & 2.5 & 9.7 & 19.7 & 60 & 2 & 2 & inv & 0.5 & 0.02 \\
\hline 16 & Evi & $\mathrm{A}^{\circ}$ de las Viñas & 355 & 48 & 2.4 & 9.3 & 19.9 & 50 & 2 & 3 & 0.006 & 0.3 & 0.01 \\
\hline 17 & Em & Canuto del Moro & 9 & 1.6 & 1.2 & 7.5 & 12.3 & 880 & 1 & 1 & inv & inv & inv \\
\hline 18 & Emc & C. Molino de las Cuevas & 12 & 2.1 & 1.7 & 7.8 & 12.1 & 800 & 1 & 1 & inv & inv & inv \\
\hline 19 & Eml & Canuto del Moral & 9 & 1.7 & 1.3 & 8.8 & 12.4 & 700 & 1 & 1 & inv & inv & inv \\
\hline
\end{tabular}

fore could not be sampled. In August there was only superficial water in E1, Ecñ, Epbm, Epbh, Eo, Ero, Esa, and Evi sampling sites (Table 1). In December the sampling sites Epbm, Epbh, Ega, and Evi were inaccessible after autumn rains.

A kick net of $0.3 \times 0.3 \mathrm{~m}$ opening and $0.5 \mathrm{~mm}$ mesh size and the same unit of effort in all the localities (three replicates per site) was used for the extraction of the macroinvertebrates. All habitats were sampled along a $50 \mathrm{~m}$ riverbed stretch. The samples were fixed using $70 \%$ alcohol and later identified to species level in the laboratory. Five Hydropsychidae (Diplectrona felix, Hydropsyche infernalis, $H$. Siltalai, H. Lobata, and H. iberomaroccana) and two Rhyacophilidae (Rhyacophila munda and Rhyacophila fonticola) species were identified. Because of the taxonomic difficulties in identifying $H$. Iberomaroccana larvae, this study was complemented with adult records.

For the physical-chemical analysis, samples in February (winter), June (spring), August (summer), and December (autumn) were taken. The average values of the analysed parameters are shown in Table 1. a)

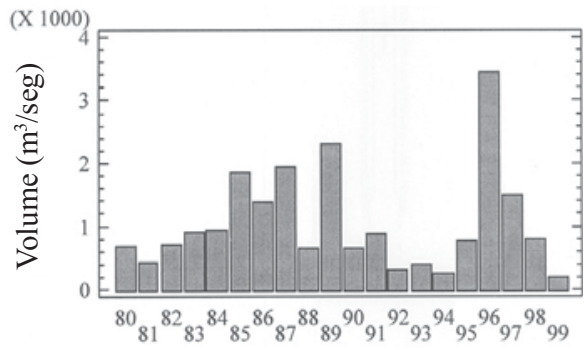

b)

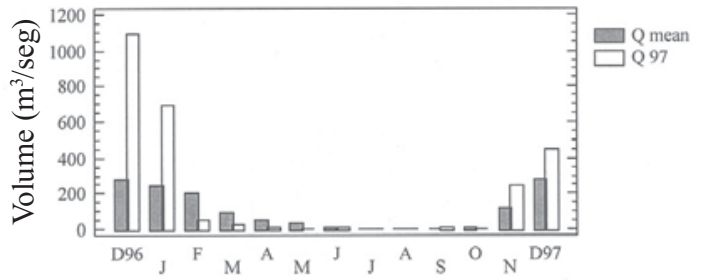

Figure 2. a) Registered average annual flows in twenty years in the water gauge station of Jimena de la Frontera. Discharge values $\times 1$ 000. Caudal anual medio registrado durante veinte años en la estación de aforo de Jimena de la Frontera. Caudal $\times 1$ 000. b) Comparison of the monthly average discharges (Qmean) of the temporal series 1981-99 with the registered ones in 1997 (Q97), measures in the water gauge station of Jimena de la Frontera. Elaborated from the database of Confederación Hidrográfica del Sur de España. Comparación del caudal medio mensual (Qmean) de la serie temporal 1981-99 con los registrados en 1997 (Q97), medidos en la estación de aforo de Jimena de la Frontera. Elaborado a partir de la base de datos de la Confederación Hidrográfica del Sur de España. 


\section{Data analysis}

For the physical-chemical characterisation of the basin a Principal Component Analysis (PCA) on physical-chemical parameters $\times$ localities data matrix was performed. To establish the environmental features of the river system, the four most explanatory variables in a previous work in the area (Ruiz et al., 2006) were selected: altitude, conductivity, dissolved oxygen, and temperature.

The ordination method used was selected based on the length of the gradient calculated by Detrended Correspondence Analysis (DCA) (Bonada et al., 2005). Since the first DCA axis has a gradient length of 5.2 standard deviation units, the use of a unimodal ordination technique was justified. To study the relationship between environmental variables and species, a Canonical Correspondence Analysis (CCA) with seasonal abundance data was performed. The significance of CCA axes was tested with the Monte Carlo permutation test (999 unrestricted permutations, $P<0.005$ ). All variables used were log-transformed to achieve normality. All the analyses were performed with the PCORD program. To test for the influence of water permanence (seasonality) on the species' distribution a Kruskal-Wallis test was used. To test

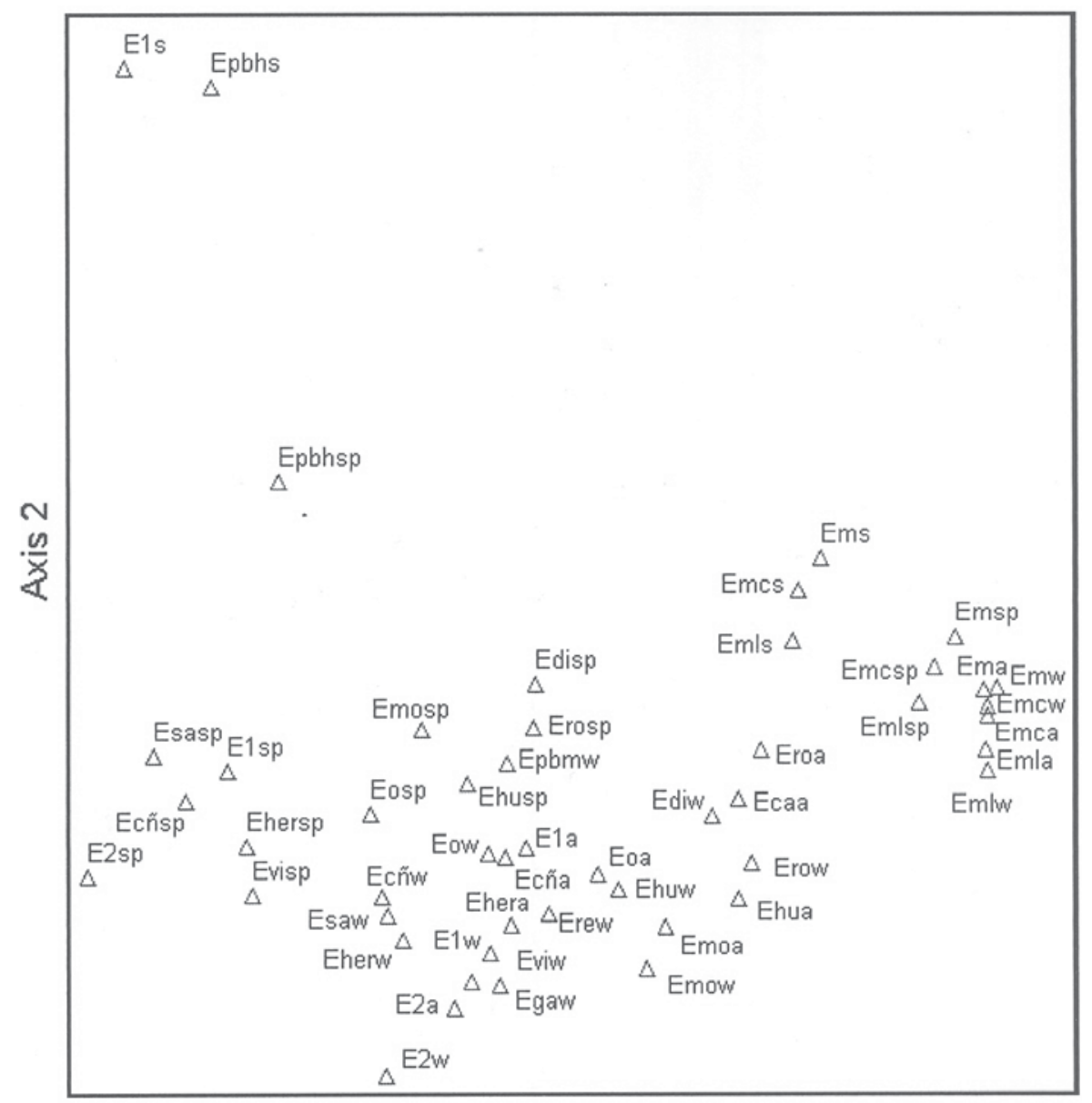

Axis 1

Figure 3. Classification by Principal Component Analysis based on four selected environmental variables (altitude, conductivity, dissolved oxygen and temperature) of sampling sites of the Hozgarganta catchment. Clasificación de las localidades muestreadas en la Cuenca del río Hozgarganta mediante un Análisis de Componentes Principales basado en cuatro variables (altitud, conductividad, oxígeno disuelto y temperatura). 
the thermal preferences of species an adjusted average temperature (AAT) was calculated (Gallardo-Mayenco et al., 1998).

\section{RESULTS}

The first PCA axis accounted for $52.9 \%$ of the variance and shows sampling sites ordered according to altitude and water conductivity, representing a geomorphologic and water permanence gradient, where headstream sites (Em, Eml and Emc) have permanent conditions (Fig. 3). The negative end of this axis was associated to spring samples of downstream sites (E2, Ecñ, E1 and Esa), where high values of both conductivity and temperature were registered. The second PCA axis explained $28.2 \%$ of the variance (the cumulative variance was $81.1 \%$ ). This axis distributed the sampling sites according to the concentration of dissolved oxygen (Fig. 3). We can see that the summer samples from E1 and Epbh are separated from others due to the low value of the dissolved oxygen. Seasonality was of little importance in explaining the sites' distribution.

The CCA performed from seasonal data showed that the total variance ("inertia") was 2.75 ; in the procedure three canonical axes were ob-

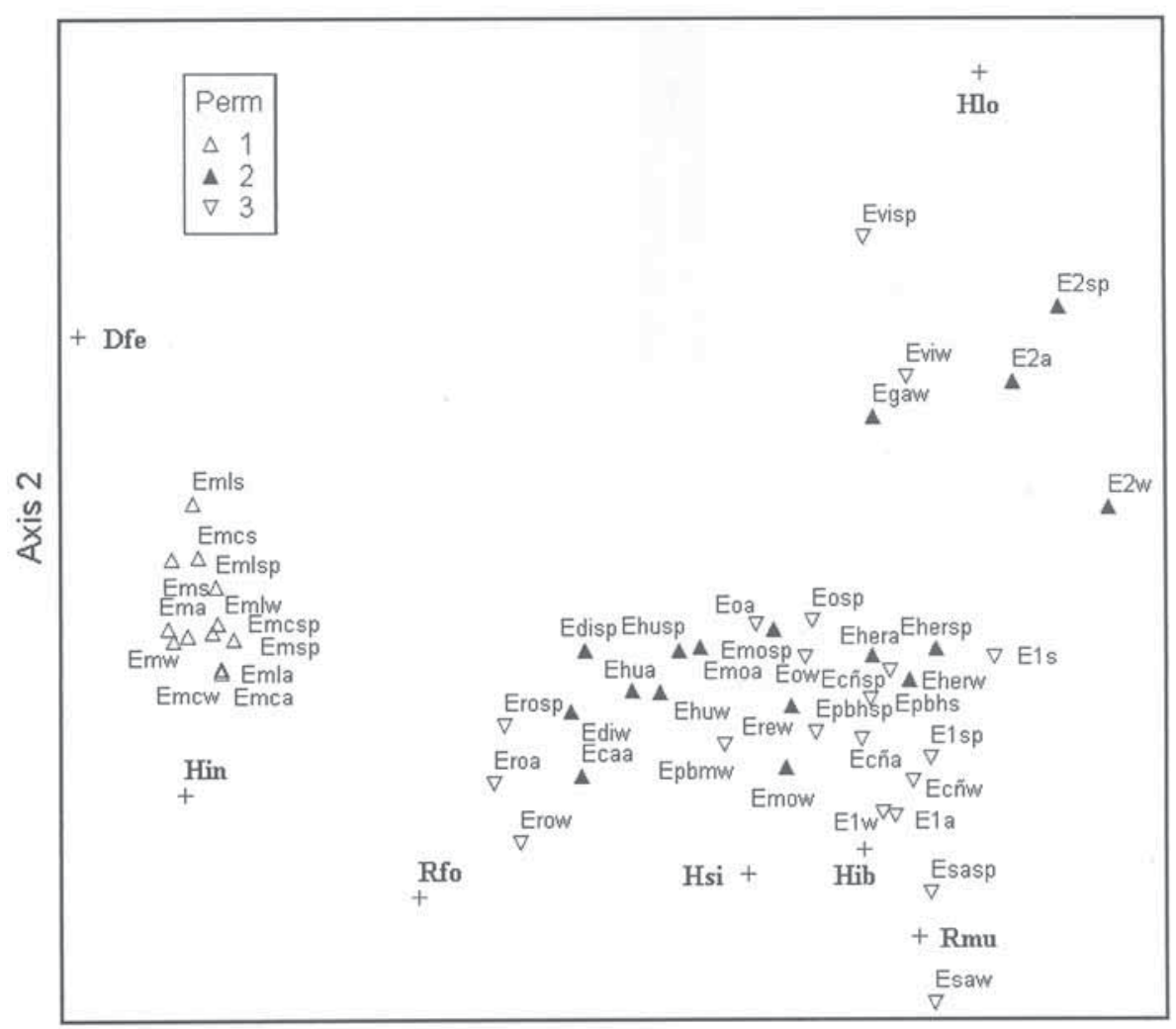

Axis 1

Figure 4. Projection of the two first axis of the CCA with seasonal data. Symbol code categories of season (winter (w); spring (sp); summer (s) and autumn (a)) are showed at the end of the acronyms of the sites. Symbol code categories of the variable water permanence (Perm) as follow: 1. permanent; 2. ephemeral; 3. intermittent. + symbol show species. Species codes are explained in Table 2. Sites codes are explained in Table 1. Proyección de los dos primeros ejes de un CCA con datos estacionales. El código de las estaciones del año (invierno (w); primavera $(s p)$; verano $(s)$ y otoño $(a)$ ) aparece al final de los acrónimos de las localidades de muestreo. El código de las categorías de la variable permanencia del agua en el cauce (Perm) es el siguiente: 1. permanente; 2. efímera; 3. intermitente. El símbolo + representa a las especies. El código de las especie es el mismo que aparece en la Tabla 2. El código de las localidades de muestreo aparece en la Tabla 1. 
Table 2. Seasonality influence of the channels (permanent/ intermittent/ ephemeral) in the species distribution calculated with the Kruskal-Wallis test. Significant $p$-values $(P<0.005)$ are show in bold. Influencia de la estacionalidad de los cursos de agua (permanentes/ intermitentes/efimeros) en la distribución de las especies, calculada con el test de Kruskal-Wallis. Los valores significativos del ajuste $(\mathrm{P}<0.005)$ aparecen en negrita.

\begin{tabular}{lccc}
\hline species & code & k-w test & p-value \\
\hline D. felix & Dfe & 17.84 & $\mathbf{0 . 0 0 0}$ \\
H. infernalis & Hin & 12.04 & $\mathbf{0 . 0 0 2}$ \\
H. siltalai & Hsi & 4.1 & 0.128 \\
H. iberomaroccana & Hib & 9.87 & $\mathbf{0 . 0 0 7}$ \\
H. lobata & Hlo & 5.2 & 0.073 \\
R. fonticola & Rfo & 2.5 & 0.275 \\
R. munda & Rmu & 4.58 & 0.100 \\
\hline
\end{tabular}

tained. The Monte Carlo test indicated that only the first two axes were significant ( $p=0.005)$. The first axis explained $28.8 \%$ of the variance; the second one $6.7 \%$. The cumulative variance was $35.4 \%$. We obtained that the variables strongly related to the first axis were altitude $(r=-0.91)$ and conductivity $(r=0.88)$, and the temperature was weakly related with the second axis $(r=0.18)$. The percentage of unexplained variance was $64.6 \%$.

Figure 4 shows sites and species distributed in the plane formed by axes 1 and 2. Axis 1 placed the species from left to right according to altitude. $D$. felix and $H$. infernalis occupied headstreams; $R$. fonticola and $H$. siltalai inhabited middle streams and the others were downstream species.

The second factor that determined species' distribution was water temperature and conductivity. The low half of axis 2 (Fig. 4) grouped most of the high conductivity sites, whereas the top half of this axis discriminated sampling sites with high temperature. Table 2 and figure 5 show the species significantly related $(p<0.05)$ to flow permanence. D. felix and H. infernalis were significantly present in permanent conditions, $H$. iberomaroccana inhabited intermittent sites, while $R$. munda, R. fonticola, $H$. siltalai, and $H$. lobata did not show a preference to a particular habitat. $R$. fonticola was mainly associated with the Ero site (intermittent conditions), though it also occupied headwaters (permanent condi-
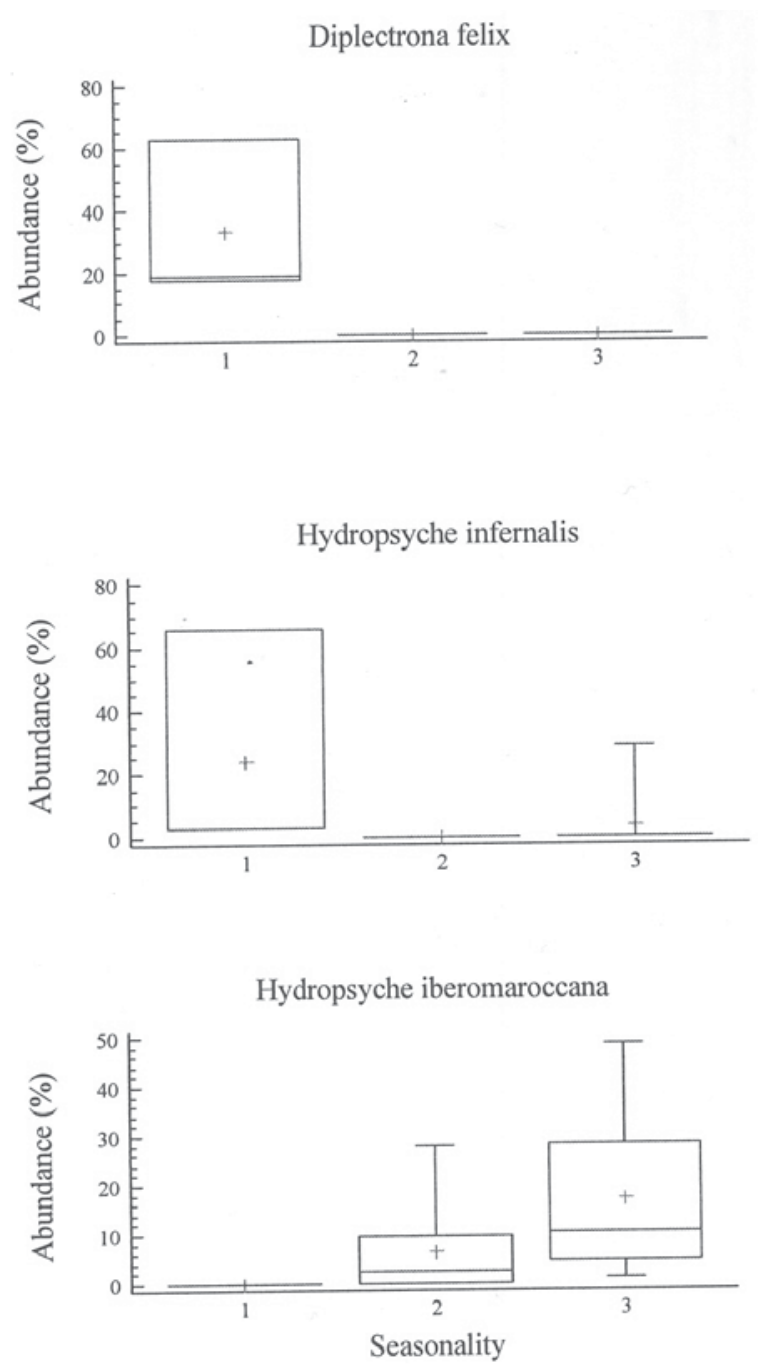

Figure 5. Box-plot showing the abundance distribution of the three significantly selected species in the kruskal-Wallis test according to water permanence in the channels. Code of the $\mathrm{X}$ axis: 1. permanent; 2. ephemeral and 3. intermittent. Distribución de la abundancia de las tres especies significativamente seleccionadas por el test de Kruskal-Wallis en función de la permanencia del agua en los cauces. Eje X: 1. permanente; 2. efímero; 3 intermitente.

tions); H. siltalai dominated the winter sample from the Emo site (ephemeral conditions). On the other hand, H. lobata occupied low reaches, in both intermittent and ephemeral sites (Evi, Ega and E2 stations).

$D$. felix and $H$. infernalis were present in cool water conditions (12.1 and $12.8^{\circ} \mathrm{C}$ of AAT, respectively); $H$. siltalai and $H$. iberomarocca- 
na were found in sites of moderate temperature (17.7 ${ }^{\circ} \mathrm{C}$ and $17.38^{\circ} \mathrm{C}$ of AAT, respectively); and, H. lobata preferred warm conditions $\left(19.4^{\circ} \mathrm{C}\right.$ of AAT). On the other hand, the Rhyacophilids species showed a similar pattern of thermal preferences, where $R$. fonticola occupied the cool water sites $\left(12.45^{\circ} \mathrm{C}\right.$ of AAT), while $R$. munda was abundant in warm waters $\left(18.01^{\circ} \mathrm{C}\right.$ of AAT).

\section{DISCUSSION}

Numerous studies have pointed out the replacement of species of Hydropsychidae along the watercourse (Camargo, 1992; García de Jalón, 1986; Verneaux \& Fassel, 1976; Gallardo-Mayenco et al., 1998). This succession may be a consequence of different feeding habits (Voelz \& Ward, 1992), metabolic needs (Roux et al., 1992), and both differential competitive ability and different mesh size of the species (Tachet et al., 1992).

In Mediterranean streams a strong environmental gradient between headwater and lower altitude streams has been observed (GallardoMayenco et al., 1998). In our study, the geomorphological gradient is the most important factor explaining the distribution pattern of Hydropsychid species. In the high Hozgarganta basin we have obtained an upstream assemblage, composed of D. felix and H. infernalis; H. lobata inhabits lower reaches in the main river, while $H$. iberomaroccana and $H$. siltalai are widespread throughout the study area, though $H$. iberomaroccana does not reach upstream reaches (e.g. Canutos del Moral, Molino de las Cuevas y del Moro).

Rhyacophila larvae are probably the caddisfly that are most restricted to conditions of high current speed. Their commitment to fast flow rates reflects both the distribution of their food supply and their physiological limitations (Edington \& Hildrew, 1995). Their distribution is restricted, almost exclusively, to the headwaters (Tachet et al., 2002). In our case, both Rhyacophila species display a differentiated distribution pattern. $R$. munda is a wide spectrum ecological species, inhabiting from cool upstream habitats to warm stream ones and the great lower rivers (García de Jalón \& González del Tánago, 1986). In the Hoz- garganta river, $R$. munda inhabits the principal channel and it is displaced at the headwaters by $R$. fonticola, a species characteristic of springs (Giudicelli \& Dakki, 1984) and upstreams (Ruiz et al., 2001). A similar result was obtained by García de Jalón \& González del Tánago (1986) in the Guadalteba river, where R. pascoei displaces $R$. munda at the headwaters. In the same way, Fernández-Aláez et al. (2002) found $R$. terpsichore in the upper reaches of the Boeza river, which disappeared in the lower reaches, where ubiquitous species like $R$. meridionalis and $R$. relicta appeared.

Another characteristic of the Mediterranean rivers is the irregularity of their flow, maximum in autumn and spring and minimum in summer (Giudicelli et al., 1985) and its high inter-annual variability (McElravy et al., 1989), that may imply an inter-annual variability in the conditions of temporality of one site (Del Rosario \& Resh, 2000). This determines that the temporary rivers are widely distributed by the climates of Mediterranean type (Gasith \& Resh, 1999).

The duration of the dry period has been recognised as an important factor explaining the biological diversity in these rivers (Williams \& Hynes, 1976, Abell, 1984, Williams, 1996, Bonada, 2003, Rüegg \& Robinson, 2004). Overall, the temporary rivers have fewer species than the permanent ones (Del Rosario \& Resh, 2000, Bonada, 2003, Arab et al., 2004, Rüegg \& Robinson, 2004). In this sense, Bonada (2003) suggests that the low taxonomical richness in ephemeral conditions, and the high difference in richness from permanent sites, would suggest a slow recovery from the last dry period.

Hydropsychids typically build their nets in rapidly-flowing waters (Edington \& Hildrew, 1995; Tachet et al., 2002) and in mediterranean rivers, they are indicators of riffles conditions, along with Rhyacophilids, (Bonada, 2003). Our study agrees with these results, because $D$. $f e$ lix and $H$. infernalis are restricted to the upstream reaches; $H$. siltalai. $R$. munda and $R$. fonticola either inhabit intermittent streams or are indifferent to water permanence. In this case, their life cycle is adapted to these environmental conditions, finishing their larval growth in the 
wet period (winter-spring). However, H. iberomaroccana and $H$. lobata displayed populations throughout the year, despite the fact that they prefer temporary conditions. Our results are in agreement with those by Gallardo-Mayenco et al. (1998) that, in a study of Hydropsychid species in the Guadaira and Guadalete river basins, point out the opportunistic behaviour of $H$. iberomaroccana (as $H$. punica), specially due to its capacity to colonise and thrive in temporary habitats. In the Hozgarganta river these species spend the dry season (summer) living in isolated pools, where the absence of superficial flow is noticeable. Numerous studies highlighted the effects of water velocity on the distribution of Hydropsychidae species. Overall, downstream species seem to be more tolerant to low velocity conditions than upstream species (Tachet et al, 1992). Hildrew and Edington (1979) showed that $H$. pellucidula, a sister species to $H$. iberomaroccana, was indifferent or more abundant in low velocity sites. On the other hand, the interruption of the superficial flow does not necessarily imply that of an underground flow between adjacent pools that might remain connected through the aquifer. We suggest that $H$. iberomaroccana might live in a wide range of current speeds and this allows it to survive in underground-fed pools.

The coexistence of several Hydropsychid species is facilitated by microhabitat partition (Czachorowski, 1989; Harding, 1997), where substrate size and type is important in modulating species' micro distribution. However, multiple factors operate synergistically over several spatial scales and thus, influence the distribution of the Hydropsychid species (Fairchild \& Holomuzki, 2002) in addition to temporal segregation in their life histories (Recasens \& Puig, 1987). Hydrological disturbances may also facilitate the coexistence of Hydropsychid species (Resh et al., 1990). In our case, D. felix and $H$. infernalis were two coexistent species in permanent headstreams. Our data suggests that coexistence is possible, at least partially, by temporal segregation, because $D$. felix was dominant in the spring-summer season while $H$. infernalis was very scarce in summer.

\section{ACKNOWLEDGEMENTS}

We thank Tony Herrera, Juan C. Salamanca and Francisco Cano-Villegas for their assistance with the field work and two anonymous reviewers for their valuable comments and improvements on the manuscript.

\section{REFERENCES}

ABELL, D. L. 1984. Benthic invertebrates in some California intermittent stream. In: Jain, S. \& Moyle, P. (eds.). Vernal pools and intermittent streams. Institute of Ecology. Publication $n^{\circ} 28$. UC Davis. Davis, CA. 46-60 pp.

ARAB, A., S. LEK, A. LOUNACI \& Y. S. PARK. 2004. Spatial and temporal patterns of benthic invertebrate communities in an intermittent river (North Africa). Ann. Limnol.-Int. J. Lim., 40: 317327.

BASAGUREN, A. \& E. ORIVE. 1991. Los insectos tricópteros como indicadores de calidad del agua en los ríos de Vizcaya. Cuenca del Nervión. Kobie, 20: 29-50.

BLANCO, R., J. CLAVERO, A. CUELLO, T. MARAÑÓN \& J. A. SEISDEDOS. 1991. Guías naturalísticas de la provincia de Cádiz III. Sierras del Aljibe y del Campo de Gibraltar. 315 pp.

BONADA, N. 2003. Ecology of the macroinvertebrate communities in mediterranean rivers at different scales and organisation levels. Tesis de Doctorado. Universidad de Barcelona. 355 pp.

BONADA, N., C. ZAMORA-MUÑOZ, M. RIERADEVALL \& N. PRAT. 2005. Ecological and historical filters constraining spatial caddisfly distribution in Mediterranean rivers. Freshwat. Biol., 50: 781-797.

CAMARGO, J. A. 1992. Changes in a Hydropsychid guild downstream from a eutrophic impoundment. Hydrobiologia, 239: 25-32.

CZACHOROWSKI, S. 1989. Differentiation of the habitats of Hydropsychidae larvae (Insecta: Trichoptera) in the pasleka river as a result of avoidance of trophic competition. Pol. Arch. Hydrobiol., 36: 123-132.

DEL ROSARIO, R. B. \& V. R. RESH. 2000. Invertebrates in intermittent and perennial streams: Is the hyporheic zone a refuge from drying? J. N. Am. Benthol. Soc., 19: 680-696. 
EDINGTON, J. M. \& A. G. HILDREW. 1973. Experimental observations relating to the distribution of net-spinning Trichoptera in streams. Verein. Theor. Internat. Ang. Limnol., 18: 1549-1558.

EDINGTON, J. M. \& A. G. HILDREW. 1995. Caseless caddis larvae of the British Isles. A key with ecological notes. Freshwater Biological Association. $134 \mathrm{pp}$.

FAIRCHILD, M. P. \& J. R. HOLOMUZKI. 2002. Spatial variability and assemblage structure of stream hydropsychid caddisflies. J. N. Am. Benthol. Soc., 21: 576-588.

FERNÁNDEZ-ALÁEZ, C., J. DE SOTO, M. FERNÁNDEZ-ALÁEZ \& F. GARCÍA CRIADO. 2002. Spatial structure of the caddisfly (Insecta, Trichoptera) communities in a river basin in NW Spain affected by coal mining. Hydrobiologia, 487: 193-205.

FULLER, R. L. \& R. J. MACKAY. 1980. Field and laboratory studies of net-spinning activity by $\mathrm{Hy}$ dropsyche larvae (Trichoptera: Hydropsychidae). Can. J. Zool,. 58: 2006-2014.

GALLARDO-MAYENCO, A., J. PRESA \& J. TOJA. 1998. Spatio-temporal distribution and ecological preferences of coexisting Hydropsychid species (Trichoptera) in two mediterranean river basins (S. Spain). Internat. Rev. Hydrobiol., 83(2): 123-134.

GARCÍA DE JALÓN, D. \& M. GONZÁLEZ DEL TÁNAGO. 1986. Ephemeroptera, Plecoptera y Trichoptera de los principales ríos de Málaga. II Simp. del agua en Andalucía: 331-346.

GARCÍA DE JALÓN, D. 1986. Los Hydropsychidae (Trichoptera) de la cuenca del Duero. Boln. Asoc. Esp. Ent., 10: 127-238.

GASITH, A. \& V. H. RESH. 1999. Stream in mediterranean climate regions: abiotic influences and biotic responses to predictable seasonal events. Апnи. Rev. Ecol. Sist., 30: 51-81.

GIUDICELLI, J. \& M. DAKKI. 1984. Les sources du Moyen Atlas et du Rif (Maroc): faunistique (description de deux espèces nouvelles de Trichoptères), écologie, interêt biogéografique. $B i j$ dragen tot de Dierkunden, 54(1): 83-100.

GIUDICELLI, J., M. DAKKI \& A. DIA. 1985. Caractéristiques abiotiques et hydrobiologiques des eaux courantes méditerranéenes. Verth. Internat. Verein. Limnol., 22: 2094-2101.

GONZÁLEZ, M. A., D. GARCIA DE JALÓN \& L. W. DA TERRA. 1987. Faunistic studies on Iberian Trichoptera: a historical survey and present state of knowledge. In: Proc. of the $5^{\text {th }}$ Int. Symp. on Trichoptera. M. Bournaud \& H. Tachet (eds.): 8590. Dr. W. Junk Publisers, Dordrecht.

HARDING, J. S. 1997. Strategies for coexistence in tow species of New Zealand Hydropsychidae (Trichoptera). Hydrobiologia, 350: 25-33.

HILDREW, A. G. \& J. M. EDINGTON. 1979. Factors facilitating the coexistence of Hydropsychid caddis larvae (Trichoptera) in the same river system. Journal of Animal Ecology, 48: 557-576.

JURADO-DOÑA, V. 2002. Los bosques de la sierra del Aljibe y del Campo de Gibraltar (Cádiz y Málaga). Ecología, transformaciones históricas y gestión forestal. Consejería del Medio Ambiente. Junta de Andalucía. 219 pp.

MACKAY, R. J. \& G. B. WIGGINS. 1979. Ecological diversity in Trichoptera. Ann. Rev. Entomol., 24: 185-208.

McELRAVY,E. P., G. A. LAMBERTI \& V. H. RESH. 1989. Year-to-year variation in the aquatic macroinvertebrate fauna of northern California stream. $J$. N. Am. Benthol. Soc., 8(1): 51-63.

OSBORNE, L. L. \& E. E. HERRICKS. 1987. Microhabitat characteristics of Hydropsyche (Trichoptera: Hydropsychidae) and the importance of body size. J. N. Am. Benthol. Soc. 6: 115-124.

PRENDA, J. \& A. GALLARDO-MAYENCO. 1999. Distribution patterns, species assemblages and habitat selection of the stoneflies (Plecoptera) from two mediterranean river basins in Southern Spain. Internat Rev. Hydrobiol., 84(6): 595-608.

RECASENS, L. \& M. A. PUIG. 1987. Life cycles and growth patterns of trichoptera in the Matarraña, a karstic river. In: Proc. of the $5^{\text {th }}$ Int. Symp. on Trichoptera. M. Bournaud \& H. Tachet (eds.): 247-251. Dr. W. Junk Publishers, Dordrecht: 247-251.

RESH, V. H. 1982. Age structure alteration in a caddisfly population after habitat loss and recovery. Oikos, 38: 280-284.

RESH, V. H. 1992. Year to year changes in the age structure of a caddisfly population following loss and recovery of a springbrook habitat. Ecography, 15: 314-317.

RESH, V. H., J. K. JACKSON \& E. P. McELRAVY. 1990. Disturbance, annual variability and lotic benthos: examples for a California stream influences by a mediterranean climate. Mem. Ist. Ital. Idrobiol., 47: 309-329.

ROUX, C., H. TACHET, M. BOURNAUD \& B. CELLOT. 1992. Stream continuum and metabolic rate 
in the larvae of five species of Hydropsyche (Trichoptera). Ecography, 15: 70-76.

RÜEGG, J. \& C. T. ROBINSON. 2004. Comparison of macroinvertebrate assemblages of permanent and temporary streams in an Alpine flood plain, Switzerland. Arch. Hydrobiol., 161: 489-510.

RUIZ, A., SALAMANCA-OCAÑA, J. C. \& M. FERRERAS-ROMERO. 2001. Fauna de tricópteros (Insecta: Trichoptera) de cursos de agua que drenan canutos del Parque Natural Los Alcornocales (Sur de España). Boln. Asoc. Esp. Ent., 25(34): 105-120.

RUIZ GARCIA, A., A. F. HERRERA GRAO \& M. FERRERAS-ROMERO. 2006. Distribution of Trichoptera communities in the Hozgarganta catchment. (Los Alcornocales Natural Park SW Spain). Internat. Rev. Hydrobiol., 91(1): 71-85.

TACHET H., J. P. PIERROT, C. ROUX \& M. BOURNAUD. 1992. Net-building behaviour of six Hydropsyche species (Trichoptera) in relation to current velocity and distribution along the Rhône River. J. N. Am. Benthol. Soc., 11: 350-365.

TACHET, H., P. RICHOUX, M. BOURNAUD \& P.
USSEGLIO POLATERA. 2002. Invertebrés d'eau douce. Systématique, biologie, écologie. CNRS editions. 587 pp.

VERNEAUX, J. \& B. FASSEL. 1976. Larves du genre Hydropsyche (Trich., Hydropsychidae). Taxonomie, données biologiques et écologiques. Annls. Limnol., 12(1): 7-16.

VOELZ, N. A. \& J. V. WARD. 1992. Feedings habits and food resources of filter-feeding Trichoptera in a regulated mountain stream. Hydrobiologia, 231: 187-196.

WIGGINS, G. B., R. J. MACKAY \& I. M. SMITH. 1980. Evolutionary and ecological strategies of animals in annual temporary pools. Arch. Hydrobiol. Suppl., 58: 97-206.

WILLIAMS, D. D. \& H. B. N. HYNES. 1976. The ecology of temporary streams. I. The fauna of tow Canadian streams. Int. Rev. ges. Hydrobiol., 61: 761-787.

WILLIAMS, D. D. 1996. Environmental constraints in temporary waters and their consequences for the insect fauna. J. N. Am. Benthol. Soc., 15(4): 634650. 